\title{
DANAUS AND AUGUSTUS
}

\begin{abstract}
Summary: Four bronze cows by Myron, the Athenian sculptor, stood in front of Apollo's temple on the Palatine hill, which Octavian dedicated in 28 BCE. They were placed close to the altar and the statue of this god, in the courtyard of the temple, whose portico was decorated with statues of the 50 daughters of Danaus. The meaning of those statues is clarified by a passage from Pausanias, who tells the story of Danaus coming to Argos and claiming kingship for himself, even if in competition with Gelanor. Suddendly a herd of cows appeared in front of the city, led by a bull. A wolf challenged him, fought, won, and became the leader of the herd. This omen pointed at Danaus as the chosen one for kingship, and he had thus a temple to Apollo built as a thanksgiving to the author of the prodigy. This was an evident comparison to the story of Octavian himself, who won the competition for political leadership in Rome thanks to Apollo.
\end{abstract}

Key words: Augustus, Apollo, Danaus, Aeschylus, Myron, Argos

Everything in the Augustan culture had a meaning and nothing was haphazardly conceived. The task of historians, archaeologists and philologists is that of recognizing the logic and the conveyed messages of art, poetry, and architecture of a very sensible period in which a new fundamental institution was created, that of the emperor.

Within the ideological work of Augustus and his intelligentsia the god Apollo played a major role. Octavian vowed Apollo's temple on the Palatine hill in 36, during the Civil War against Sextus Pompeius, and at the same time he built his new residence close to the temple. ${ }^{1}$ The shrine was dedicated in $28 \mathrm{BCE}{ }^{2}$

Apollo was the most important god of the Civil War, which was highly honored by Brutus and Cassius, and which led Octavian to shed the blood of many citizens, just as Orestes did when killed Aegisthus and Clytemnestra. However, Octavian represented Apollo without any qualities or features that could recall the Civil War, but rather was made to serve in his role as the god of poetry, music, and other

\footnotetext{
${ }^{1}$ Vell. Pat. II 81; Cass. Dio XLIX 15.

${ }^{2}$ Cass. Dio LIII 1. 3.
} 
arts. $^{3}$ Apollo Actiacus is represented on Augustan coins as playing the lyre, i.e., in his pacific habit, as he is described by Propertius. ${ }^{4}$

Every element in this monument had an ideological meaning and the representations of Apollonian myths were allusions to Augustan politics. In this paper I will deal only with some Argive myths concerning Danaus, which have never been clarified hitherto. My question is: what is the reason why Octavian wanted statues of Danaus and his 50 daughters in the courtyard of this temple? And why also four bronze cows at the center of this courtyard, close to the altar of the god?

The temple of Apollo is described by Propertius with the following words:

Quaeris, cur veniam tibi tardior? aurea Phoebi porticus a magno Caesare aperta fuit.

tota erat in spatium Poenis digesta columnis, inter quas Danai femina turba senis.

hic equidem Phoebus visus mihi pulchrior ipso marmoreus tacita carmen hiare lyra;

atque aram circum steterant armenta Myronis, quattuor artificis, vivida signa, boves.

tum medium claro surgebat marmore templum, et patria Phoebo carius Ortygia:

in quo Solis erat supra fastigia currus, et valvae, Libyci nobile dentis opus;

altera deiectos Parnasi vertice Gallos, altera maerebat funera Tantalidos.

deinde inter matrem deus ipse interque sororem Pythius in longa carmina veste sonat.

(Prop. II 31)

You ask why I come to you late? Today Phoebus's gold colonnade was opened by mighty Caesar; such a great sight, laid out with columns from Carthage, and between them the crowd of old Danaus's daughters.

He who seemed to me more beautiful than the true Phoebus, lips parted in marble song to a silent lyre. And, round the altar, stood four of Myron's cattle, carved statues of oxen, true to life.

Then in the midst, the temple reared up in bright marble, dearer to Phoebus than his Ortygian land. Right on the top were two chariots of the Sun, and the doors of Libyan ivory, beautifully done. One mourned the Gauls thrown off Parnassus's peak, and the other the death of Niobe, Tantalus's daughter. Next the Pythian god himself was singing, in flowing robes, between his sister and mother. ${ }^{5}$

\footnotetext{
${ }^{3}$ Prop. IV 6.

${ }_{5}^{4}$ Prop. III 11, and also Verg. Aen. VIII 671-731.

${ }^{5}$ Prop. II 31, transl. Kline.
} 
Ovid also gives a short description of this part of the temple:

inde tenore pari gradibus sublimia celsis ducor ad intonsi candida templa dei, signa peregrinis ubi sunt alterna columnis, Belides et stricto barbarus ense pater, quaeque viri docto veteres cepere novique pectore, lecturis inspicienda patent.

(Trist. III 1. 59-62)

Then I was led up the high stairway's even steps, to the sublime, shining temple of unshorn Apollo, where statues alternate with exotic pillars, Danaids, and their foreign father with naked sword: and all that men of old and new times thought, with learned minds, is open to inspection by the reader. ${ }^{6}$

It is also clear that close to the temple, in front of the library of Apollo, a portico was built, in which statues of the 50 Danaides stood and decorated the intercolumniations. ${ }^{7}$ Danaus was represented as well. Many archaeologists identify these statues with a series of black marble girls discovered in the excavations in this area. ${ }^{8}$ Aegyptus and his sons were possibly placed in other intercolumniations in order to surround the courtyard and the central altar, but this is uncertain.

The sculptural complex was thus devoted to Argive mythology, because Danaus was the ancestor of the Argive kings.

This area also gave access to the Apollonian library, whose first director was Julius Hyginus, an imperial freedman. In a passage of his works, Hyginus says that the prince took Orestes' bones from Aricia and buried them in the Roman Forum. ${ }^{9}$ Orestes, a famous Argive king, was thus important to Augustus, who was somehow similar to him, because they were both inspired by Apollo and freed their homeland from tyranny. The paper by Martin Spannagel, in these proceedings, will clarify the meaning of Orestes within the Augustan ideology.

Danaus, the father of Danaides, was a Libyan who went to Argos and founded the Argive royal dynasty, from which also the Macedonian kings descended. Offsprings of these kings were also, in turn, the Macedonian kings themselves. ${ }^{10}$ The basic story of Danaus was narrated by Aeschylos, in his Supplices, a tragedy of the 5 th century BCE, in which the hostility between the Libyan Danaus, with his 50 daughters, and Aegyptus, with his 50 sons, is described, and the exile of Danaus to Argos as well, where he was hosted and protected by king Aegeus.

${ }^{6}$ Ovid. Trist. III 1. 59-62, transl. Kline (except foreign instead of savage, to translate barbarus).

${ }^{7}$ Prop. II 31. 4.

${ }^{8}$ PAPINI, M.: Gli dei protettori di Augusto. In Augusto [Catalogue of the Augustus Exhibition Rome 2013-2014] Ed. E. LA ROCCA. Milan 2013, 219-229, and the file by M. CIMA at p. 226.

${ }^{9}$ Hyginus, Fab. 261.1.

${ }^{10}$ See MASTRocinque, A.: Alessandro a Menfi. In WiLl, W. - HeinRichs, J. (Hrsg.): Zu Alexander d. Gr. FS G.Wirth. Bd I. Amsterdam 1987, 289-307. 
The portico of the Danaides surrounded the courtyard of Apollo's temple. In front of the temple there were a tall statue of Apollo ${ }^{11}$ and an altar, surrounded by four magnificent bronze cows by Myron, a 5th century Greek sculptor. ${ }^{12}$ In particular, a cow was famous for its realistic features and was represented on gold coins of Augustus and of Vespasian. ${ }^{13}$ Modern scholars thought that those cows simply represented sacrificial animals. ${ }^{14} \mathrm{We}$ could say, instead, that within the Apollonian temple nothing was banal or done without much premeditation. For example, the Campana slabs in the National Museum of Rome (that on the Palatine hill) which represent Hercules disputing with Apollo for the Delphic tripod are far from a mere decorative pattern. They alluded to Octavian and Antony, disputing for leadership. Antony, in fact, was a supposed descendent of Hercules, ${ }^{15}$ and Octavian was protected by Apollo. The cows, far from being a truistic allusion to sacrifices, made sense within the whole artistic program of the Apollonian courtyard. The cows had a precise meaning, for they were the protagonists of an Argive myth, which is told by Pausanias:

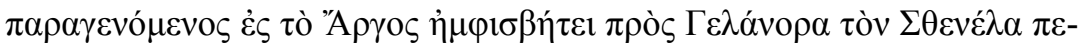

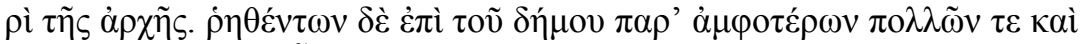

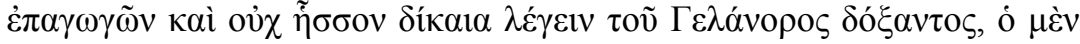

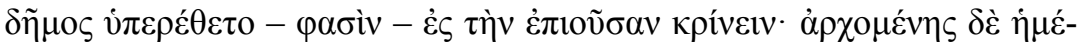

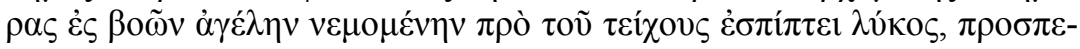

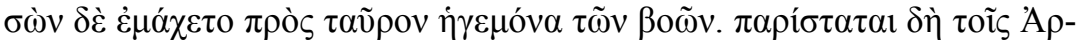

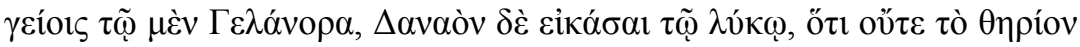

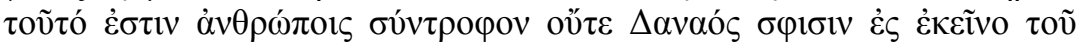

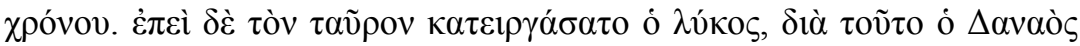

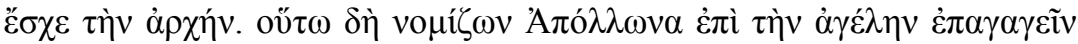

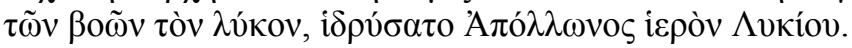

On coming to Argos Danaus claimed the kingdom against Gelanor, the son of Sthenelas. Many plausible arguments were brought forward by both parties, and those of Sthenelas were considered as fair as those of his opponent; so the people, who were sitting in judgment, put off, they say, the decision to the following day. At dawn a wolf fell upon a herd of oxen that was pasturing before the wall, and attacked and fought with the bull that was the leader of the herd. It occurred to the Argives that Gelanor was like the bull and Danaus like the wolf, for as the wolf will not live with men, so Danaus up to that time had not lived with them. It was because the wolf overcame the bull that Danaus won the kingdom. Accord-

\footnotetext{
${ }^{11}$ See also Plin. NH XXXIV 43.

${ }_{13}^{12}$ Prop. II 31. 7-8.

${ }^{13}$ Ovid. Ex Pont. IV 1. 34; on the coins: Rambach, H. - WalKer, A.: The 'Heifer' Aurei of Augustus. Schweizerische Numismatische Rundschau 91 (2012) 41-62.

${ }^{14}$ Cf. D. BRuno in CARANDinI, A. - BRUNO, D.: La casa di Augusto. Dai "Lupercalia" al Nata-

${ }^{15}$ Plut. Ant. 4: "the Antonii were Heracleidae, being descendants of Anton, a son of Heracles".
} le. Rome 2008, 204. 
ingly, believing that Apollo had brought the wolf on the herd, he founded a sanctuary of Apollo Lycius. (Paus. II 19. 3-4)

This Argive myth got a new meaning within the Apollonian temple on the Palatine hill. Here the fight for the leadership was an allusion to Augustus and his enemies. Other enemies were especially alluded to in the iconography of this temple, and in particular Cleopatra, who represented Egypt, and therefore Cleopatra and Egypt were enemies of Danaos and Apollo. Aegyptus, in fact, was king of Egypt. The cows by Myron alluded to the help that Apollo gave to Danaus to overcome his rival.

Danaus, ancestor of Greek kings, was a Greek counterpart to the Roman founder of a new series of rulers, Augustus. The wolf, in the prophetic vision, represented Danaus, and the bull his enemy Gelanor. Therefore a clear correspondence was recognizable by people who went to the temple of Apollo:

\begin{tabular}{|l|l|}
\hline Danaus & Aegyptus \\
\hline Danaus & Gelanor \\
\hline wolf & bull \\
\hline Augustus & Cleopatra \\
\hline
\end{tabular}

In the opposition Danaus versus Aegyptus, the Egyptian allusion is evident. The case of the opposition Danaus versus Gelanor could allude either to Octavian against Antony or to Octavian against Cleopatra.

The myth of Danaus and his Augustan revival were known, moreover, at Tarsus, which was a supposedly Argive colony that worshipped Apollo Lykeios. It is difficult to know when this Argive origin was established, for it was probably a pure fiction in order to ennoble this city. In the imperial age such an origin, with the related Apollonian worship, opportunely served the purpose of pleasing Augustus and the subsequent Roman emperors. ${ }^{16}$ Some bronze coins of Tarsus preserve the best image of Apollo with his wolves, namely Apollo Lykeios.

In the Augustan and Tiberian Age images of the conquered bull were found everywhere in Rome and within the Roman Empire. Everyone was able to recognize a celebration of Augustus in such images, even if, instead of Augustus, Victory was represented. Mithras-Apollo was a more sophisticated product of the imperial ideology, but the ideological message was always the same: Augustus claimed his military victories by virtue of the help of his personal god.

The Augustan mint of Lyon issued a series of aurei and denarii on whose reverse a butting bull is represented. ${ }^{17}$ This scene has been interpreted ${ }^{18}$ as a commemo-

${ }^{16}$ RoBert, L.: Documents d'Asie Mineure. IV: Deux inscriptions d'Argos et de Tarse. $B C H 101$ (1977) 88-129. However, we must be cautious, because Soloi, a city close to Tarsus, was another alleged Argive colony early in the 2nd century BCE: Pol. XXI 24. 11.

${ }^{17}$ RIC I 53-54, nos. 176-178, 186-189.

${ }^{18}$ KRAFT, K.: Zur Münzprägung des Augustus [Sitzungsberichte der wiss. Gesellschaft an der Johann Wolfgang Goethe-Universität Frankfurt am Main 7.5] Wiesbaden 1969, 229-232; on the derogatory use of the surname Thurinus, used by the Antonian party, see 227 . This bull is therefore not an allusion to 
ration of the victory at Philippi, because similar issues with the same obverse show Diana, alluding to Augustus' victory over Sextus Pompeius in Sicily (36 BCE), and Apollo, alluding to his victory over Antony at Actium (31 BCE). Coins with Apollo and with the bull were roughly contemporary, for they report the same tenth imperatorial acclamation (ca. 15-12 BCE). The bull has nothing to do, specificially, with Philippi, but it represents his conquered enemies. This bull on Augustan iconographies had the same meaning as Myron's herd in the temple of Apollo, where Danaus' victory over Gelanor was celebrated.

A Greek counterpart of Augustus was highly opportune in a temple where festivals were celebrated in oder to make Greek and Latin artists contend in a game of arts, instead of a game of weapons. Apollo did not want to fight any more, and preferred the lyre to the arrows. Augustus versus Danaus was an appropriate parallel case in a temple whose library gathered the most important pieces of literature from both the Greek and Roman world.

\author{
Attilio Mastrocinque \\ Dipartimento Filologia, Letteratura, Linguistica, Tempo, Spazio, Immagine, Società \\ Settore disciplinare Storia Romana \\ Università degli studi di Verona \\ Viale Università, 4 \\ 37129 Verona \\ Italia
}

the surname. Some silver denarii (RIC I 79, no. 475) represent a standing bull, and C. H. V. SUTHERLAND
(L'attribution des deniers augustéens aux types du «temple », de la « couronne » et du « jeune taureau ».
Revue Numismatique 16 [1974] 4-67, esp. 61-67 [cf. RIC I 35]) supposed this was a celebration of Po-
seidon at Samos, which Augustus visited in 20 BCE. 